\title{
Formation of New Eastern Limes of Central Europe: Relations and Policy of European Union and Ukraine towards Cross-border Cooperation after the European Union Enlargement Yeva KISH
}

\author{
ÚКафедра історії Угорщини та європейської інтеграції, \\ Гуманитарно-природничий факультет з угорською мовою навчання, \\ Ужгородський національний університет, \\ Университетская 14/a, 88000 Ужгород, Україна \\ Department of History of the Hungary and European Integration, \\ Faculty of Humanities and Natural Sciences with the Hungarian Language of Education, \\ Uzhhorod National University, \\ Universitetskaja 14/a, 88000 Uzhhorod, Ukraine \\ magyartortenelemtanszek-une@yandex.ru
}

Formation of new Central Europe and hence new Eastern Europe at the edge of the centuries is a multi-dimensional process that operates due to an internal logics of the development - as a single structure that is in constant interaction with the new geopolitical and geoeconomic space of the European Union, which will continuously "check" its interests - "answers" with position and reaction of new elements.

The search for European identity inside and outside (in cultural-civilizational and institutional dimensions) will take place within the search for balance of interests between the European Union and Ukraine. The geopolitical space of new Central Europe is shifting, and, as the result of it, certain historical circumstances can be changed. Thus, the rules of the game on the international arena are being changed from time to time depending upon the structure of always present future.

The process of so called "return", "union", "entering" of Central European countries to single European geopolitical space is more complicated and long-lasting process than one can imagine. For sure, the process is more complicated than fulfilling the Copenhagen criteria, and then, other vital criteria. In fact, that is a one in two process of segmentation of Central and Eastern Europe and transformation of geographical and geopolitical shape of Central Europe (Ukraine's first-rate neighbour countries). This process is of matchless importance both from the viewpoint of collapse of Central and Eastern Europe region and formation of new structure of relations on the EU level in the format: Central European countries - Ukraine.

The present future on East territories, the EU with its neighbour - Ukraine will be formed very carefully, at least in the nearest ten years. This is proved by the EU documents, speeches of the leading politicians, and especially the practice of interrelations between the European Union and Ukraine. For today, there is no policy balancing relations between the 
parties regarding the clarification of their own interests or search for mutually acceptable forms of interrelation considering the interests of each of the parties. Ukraine further actively develops "business-plans" of European integration, asks for full EU membership based on its own interests. And the European Community - in terms of available complex of problems on its Eastern borders, own reforms and necessity in additional financing to promote adaptation of the new members - tries, based on its own interests, to postpone perspectives of European integration of Ukraine as farther as possible.

Moreover, along with the orientation on own interests, both parties possess the scenario for imitation of cooperation with each other. There is no need to list so called plans, programmes or concepts, which, from strategic point of view, do not determine perspectives of European integration of Ukraine. In this regard, as for Ukraine, the experience of "forgotten region" is principally instructive. They mean the experience of integration of Central European region, which is always emphasized in Ukraine, but few of those examples are really implemented in our country.

This research discovers the essence, in our opinion, if not the only pragmatic gesture or even real segment of cooperation, proposed by the European Union to Ukraine - formation of European level of cross-border cooperation with Ukraine. The problem of formation of cross-border cooperation system in accordance with the European standards is an actual point of the theory and practice of European integration of Ukraine. Principally important is, first, the system approach to the real building of eurointegration cooperation of Ukraine and denial of declaring and imitating of euroregional cooperation in Ukraine. Secondly, today in terms of "delay" in European integration of Ukraine, especially establishment of European level in cross-border cooperation of Ukraine can become a serious specific presentation of European intentions of Ukraine, in fact, a real step towards coordination of interests between the European Union and Ukraine. It's important to emphasize, despite the cross-border cooperation is not a part of acquiscommunautaire, it is a part of regional policy of the European Union, provisions and principles which are generally adapted in the countries of the European Community.

The analysis of cross-border cooperation in Ukraine is presented by considerable corpus of publications but problematic issues in cross-border cooperation in terms of geopolitical changes on Euro-Asian space are not enough investigated and need complex research. ${ }^{1}$ So far, the perspective of association with the European Union in frames of free trading

1 М.І.ДОЛІШНІЙ - В. В.ДЕМЧЕНКО- Н. А.МІКУЛА,Концептуальні підходи до створення польсько-українського єврорегіону "Сян" на основі узагальнення досвіду єврорегіонів на західному кордоні Польщі,іn: Регіональна економіка, No. 1, 2003, 69-81; ÉvaKiss, Határmentiegyüttműködés, Pécs 2009, 454-492; Éva Kiss, Central Europe in the modern system of euregional integration, Uzgorod 2008, 440; Éva Kiss, Az Európai Unió regionális politikájának jelenlegi prioritásai, in: A határon átívelő együttmúködés perspektívái, Nyíregyháza 2008, 15-27; Eva Kiss, Logisztikai klaszter létesitésének koncepciója Kárpátalján, in: Magyar-ukrán határrégió. Együttműködés az Európai Unió külső határán, Debrecen 2008, 173-165; Éva Kiss, Az Európai Unió „keleti bővitésének" hatása Ukrajna határon átívelő együttműködési rendszerének kialakítására, in: A határon átívelő együttműködés perspektívái, Nyíregyháza 2005, 151-159; Éva Kiss, Cross-Border Cooperation between Ukraine and Hungary in View of EU Enlargement, in: Inventárium, Nyíregyháza 2005, 96-103; Éva Kish, Schengen and theHungarian-Ukrainian Border. A Ukrainian Perspective, in: Carpathian Euroregion and External Borders of the Enlarged European Union confronting the effects of Schengen, Košice 2003, 116-159; Éva Kiss, European Union Enlargement and the Impact of Schengen Visa on Creation of New Frontiers in Central Europe, in: Borders and Cross-border Co-operation in the Central European transformation countries, Debrecen 2002, 129-136; Н. МІКУЛА, Єврорегіони: досвід та перспективи, Львів 2003, 222; С.МАКСИМЕНКО, На шляху до Європи. Український досвід єврорегіонів, Київ $2000,198$. 
and visa free regime zone was replaced by the status of a neighbour, and, correspondingly, a proposal to form an Eastern "circle of friends" together with Belarus and Moldova. The EU clearly and unambiguously expressed in frames of the neighbourhood programme the intention regarding the further dynamic and deeper development of cross-border and interregional cooperation in terms of financial guarantees from the EU side.

During the nearest years, the European Union will try, first of all, to strengthen its own security, especially on new Eastern borders. Hence, the main problem the EU and Ukraine will try to find solution for, will be how to stop illegal migration and fight international crime. Furthermore, the Western borders of Ukraine form the space foreconomic, ecological and security interests of the European Union. They also form a space for introduction of pilot models for the development of good neighbourhood and cross-border cooperation that always played and today continues playing an important role in the field of associating and solidarity of Europe. The role of cross-border cooperation between the EU and Ukraine will grow due to considering transit potential of Ukraine. In this regard, cross-border cooperation should be oriented on transformation of the border from a barrier on the way of transport flows into integration factor enhancing its development.

The modern dynamic development of European integration in terms of the expanded European Union requires identification of new priorities in the field of the development of cross-border cooperation of Ukraine with the neighbour countries. Moreover, geopolitical changes, especially those in the region of Central and Eastern Europe, as the result of the $\mathrm{EU}$ expansion to the East also require formation of cross-border relations in accordance with European standards. At the same time, special attention should be paid to the facts that since 2004 cross-border cooperation between Ukraine (non-EU country) and Poland, Slovakia and Hungary (EU countries) should be conducted in accordance with European rules and principles in the context of formation and implementation of scientifically well-foundedjoint concepts for the development of neighbour countries' border territories. The cross-border relations and cross-border cooperation form an integral part as a sub-system and sub-level of a single system of international relations. At the same time, cross-border cooperation is a specific field of international and inter-state relations being implemented and based on clear criteria and principles. The analysis of the cross-border cooperation development system in terms of deepening integration processes allows to say that at present, cross-border cooperation in Europe has entered the stage of system-defined qualitative changes. On the one hand, in frames of the European Union enlarged in 2004 (from 15 to 25 member countries) the developed cross-border cooperation entered a stage of active implementation based on considerable decrease of barrier-nature internal, as for the European Union, state borders, and becomes a tool for successful implementation of joint regional policy, principle of subsidiarity, decentralized management etc., in broader understanding - building of integral "Europe of the regions". On the other hand, - on the new external borders - cross-border cooperation is being transformed into an active tool of formation by the enlarged European Union of a line of good neighbourhood and intensive development of links between the European Community and all the neighbour countries. Besides, considering new conditions, cross-border cooperation with the neighbouring EU member countries and the EU in general for the most of non-member countries and also for Ukraine, is very important (in some cases the only possible) and extremely effective way 
for practical involvement of the regions to the process of European integration in general. After a group of East-European countries had entered the EU on 1 May 2004, the status of cross-border cooperation between Ukraine and Central European countries (its Western neighbours and new member-states) has been considerably changed.

Firstly, cross-border cooperation between Ukraine and its Western neighbours - Republic of Poland, Slovak Republic and Republic of Hungary has been since May 2004 conducted strictly on new common Eastern borders of the EU. As a result, the international relations and cross-border cooperation between the Central European countries and Ukraine were transformed from the relations of "second turn" into the relations between the EU and Ukraine, as a neighbour of the first turn for the European Union and CEE countries.

Secondly, the previous cross-border cooperation of Ukraine with Republic of Poland, Slovak Republic and Republic of Hungary was represented mainly by bi- and multi-lateral relations between the countries of Central and Eastern Europe, now it stepped out of this rather limited regional scope and has been transformed into relations of Ukraine not only with individual countries of CEE, EU or their associations but into relations between Ukraine and European Union in general.

Thirdly, the cross-border cooperation between the Central European countries and Ukraine is an integral part of new policy of the European Union. ${ }^{2}$

Thus, geopolitical status of cross-border cooperation between Ukraine and Central European countries has been raised on higher level that, with no doubt, should be considered as a positive. The euroregions will also promote geostrategic transformation on Euro-Asian continent through formation of so called external circle of the EU. The interrelation between Ukraine and the EU countries on cross-border and interregional levels may become even more dynamic than that on international level. Ongoing European integration processes and the EU enlargement form favourable conditions as for Ukraine regarding the further improvement of cross-border cooperation with Central European neighbours and the EU in general, and also for starting cooperation on higher level.

Despite of specific decisions dealing with the development of euroregional movement made by Ukrainian central governments, no radical positive changes in the activity of the euroregions with participation of Ukraine took place. Vice versa, the activity of the euroregions was not ready for the process of European Union expansion and establishing the EU borders near Ukraine. The euroregions did not succeed in getting adapted to the new conditions of operation considering entering of CEE countries into the EU, and to step apart the frames of mainly declarative-political cooperation in frames of the existing euroregions. That's why the system of euroregional cooperation in whole badly needs serious transformation. ${ }^{3}$

The integral Europe is first of all, Europe of regions. Formed at the example of Dutch-German euroregion since 1990 four euroregions- Pomerania, Pro Europa Viadrina, SpreeNeisse-Bober, Neisse, which fully "covered" German-Polish and partially German-Czech border territories ("old" Eastern border of the EU), have changed their nature today, which

2 Європейська Рамкова Конвенція про транскордонне співробітництво між територіальними общинами або властями (ETS No. 106) - Мадрид, 21 травня 1980 р. European Outline Convention on trans-frontier co-operation between territorial communities or authorities from Madrid, 21 May 1980 - http://www.zakon.rada.gov.ua

3 Закон України Про транскордонне співробітництво 24 червня 2004 року, №. 1861-IV. 
is reflected in their activities. Investigation of present activities of those euroregions allows to make certain conclusions. Let's emphasize that the interest to investigate especially those euroregions is led by the fact that those euroregions underwent dynamic transformation from external into internal borders of the EU.

The analysis of euroregional experience on the border territories of Germany, Austria, Slovakia, Poland and Hungary allows to take lessons of their activity - their evolution, structures, operations, specific success or problems, the euroregions cannot deal with. Moreover, this experience is important from the viewpoint of its components adaptation to the realities of Ukraine in the context of formation of system for euroregional cooperation of Ukraine, formation of really operating, effective euroregions with participation of our country. This system is, unfortunately, not formed in Ukraine by now. There are individual examples of international but not interregional, as they use to say, cross-border cooperation to present the availability of forms of cross-border cooperation in Ukraine.

Thus, in accordance with the system of comparative analysis we identify those conceptual provisions which, in our opinion, will promote the most effective development of euroregions in Ukraine.

Structurally distinctive factors for the development of effectively operating euroregions in Ukraine in accordance with European comparative approach aredecentralization that is a basic principle of eurointegration policy. In practical dimension it meansa formation of euroregions "from the bottom" initiated by local self-governments, communities etc. The practice of present activities conducted by Ukrainian euroregions "from the top" established as international, not interregional cooperation, did not prove itself as an effective one. Priority should be given to maximal involvement of regions. Thus, the role of those regions of Ukraine should be strengthened, which possess capacity to form and develop euroregional cooperation with the other regions of Europe. It is important to deliver real, not declarative competencies in the field of euroregions formation to local self-governments of Ukraine, especially regional councils, village councils etc., based on those directions they (euroregions) would be really able to implement. Thus, the next task should be to establish new Ukrainian euroregions of European nature and transform the existing but not "acting" structures, which only imitate international European regional cooperation.

The experience of European euroregions on the borders of Germany, Poland and Czech Republic shows that the direction of those euroregions' activities were not "generally" limited, i.e. they covered all the fields of cooperation. In frames of these euroregions' activities, individual priorities were identified, having model character. What is really important is that those programmes are viable in terms of the EU enlargement to the East.

Firstly, this is a cooperation between the educational establishments of Frankfurt and Slubitse, establishment of a Viadrina University and correspondingly developed and implemented projects regarding building adynamic cooperation in the field of higher education, that today allows joint studying for the students of both countries, implementation of specific educational and research programmes by the lecturers and scientists of Germany and Poland. Secondly, this is a specific targeted cooperation in the field of environment protection on the Polish-German border - the projects dealing with building refinery constructions on the border were developed and implemented. ${ }^{4}$ The euroregion Neisse that covers Ger-

4 Бюлетень ЄвроКліп-Єврозв'язок,№. 1. Зв'язок, який єднає. Публікація здійснена Фондом ЄвроКліп-Єврозв'язок за підтримки Міністерства Закордонних Справ Угорщини, Ніредьгаза / Nyíregyháza 2005, 16. 
man, Czech and Polish territories is operating as a network of effectively operating institutional structures. Main field of activities covers the development of industry, high quality tourism and use of regions' logistics. One more example - multicultural euroregion SpreeNeisse-Bober in frames of which the development of "green", "water", "rural" tourism and involvement of traditions, culture of Lusatian Serbs to the process - finally as integral tourist "product" - differs a lot from its analogues perhaps, in picturesque Transcarpathia (border region of Ukraine with its not used tourist-recreational potential). It differs by the form of presenting world-famous "Rural Venezia" (Spreewald) and selling its final "product" - hotel services, water tourism trails, specifics of cooking meals and their patenting in various forms with the aim of advertising, sells on European continent. An optimal combination of infrastructure development and tourism specifics creates new working places, shows high level of inter-ethnic tolerance, preserves ethnic-cultural heritage of civilization mosaic of other nationalities representatives.

3. An essential aspect of euroregional development is financial issue, especially available target programmes of the EU euroregional cooperation, which differ in size of financing for the EU regions and non-member states' regions. E.g., in frames of development of euroregion "Pro Europa Viadrina" 12 million Euros were involved only for logistics and development of infrastructure, aimed at tourism development within the euroregion. Thus, not idealizing the experience of the above mentioned euroregions (there is also a wide range of problem issues), the author would like to emphasize their positive experience. Till 2004 the borders of those euroregions formed Eastern borders of the EU, so the existing problems were very similar (not the same) as those in Ukraine. Analysing the activities of these four euroregions in European context, of course touching only the borders of the countries-founders of the EU, we notice striking differences. But that would be a topic for another research. The question is to what extent Ukrainian euroregions can become creative enough to adapt positive experience of euroregional cooperation especially of Central European countries - Czech Republic, Poland, Slovakia and Hungary, and use the benefits of the EU expansion.

From the viewpoint of national interests of independent Ukraine and effective formation of Ukrainian foreign policy, including that in the field of cross-border relations, the special attention should be paid to the research of influence of geopolitical status of leading Central European countries (the closest neighbours of Ukraine which after 2004 became fullscale EU members and a part of integral European community and integral transatlantic geopolitical space) change, and on the system of international relations in the world and the region. The beginning of the third Millennium is characterized by radical changes in the systems of global and regional continental relations. Especially deep structural and system changes are taking place mainly on the European continent. They are of not only determinant regional or local significance but also influence cross-continental and world affairs. The new united enlarged Europe is being formed whose influence in the world is constantly growing. Through granting membership to 10 new countries of Central and South-Eastern Europe, at present the territory of the European Union covers 25 countries. Thus, because of the EU and NATO expansion, the zone of social and economic development, stability and security is moving eastwards, and for the first time has touched Ukrainian borders. In the result of such changes of the Central European countries' role in 
geostrategic dimension, at the beginning of $21^{\text {st }}$ century more-less integral region of Central and Eastern Europe was divided into two parts which differ a lot from each other by the level of their integration to European Community. Hence, the geopolitical status, place and role of newly-formed Central and Eastern Europe in continental - European system of international relations vary greatly.

The European Community is interested in buildinga region with sustainable economic development, political and social stability, good neighbourhood along its borders. The Community proposes to build future relations with bordering East European countries based on new strategy of interrelations. The sense of present geopolitical changes of place and role of Central European countries in frames of new system of international relations consists in their final exclusion from exclusive ring or "grey line" of potential geopolitical instability, intermediary region between East and West, and their inclusion inthe space of stability and collective security, integral European and Euro-Atlantic space of economic development and wellbeing.

The integration of Central and East European countries to the EU has provoked the change of geopolitical situation on European continent. The development of new philosophy for development of cross-border cooperation in European Union becomes of great importance. The same happens with new strategy for cross-border cooperation between the Central European countries and Ukraine, based on European principles. The task of creating new forms of cross-border cooperation is very important for border communities and regions of Ukraine, which, since May 2004, has gained the status of direct neighbours of the enlarged European Union.

The present development of cross-border cooperation of Ukraine in accordance with European criteria is caused by a number of objective factors already influencing the development of Ukrainian border regions, or would influence its future in short-term and middle-term perspectives. Those factors are:

foreign policy strategy for reapprochement between Ukraine and European Union that determines cross-border cooperation as one of the tools for European integration of the country. This is proved by the contents of Strategy and National Programme of Ukraine's integration to the European Union which determine cross-border and interregional cooperation between the local self-governments as one of the possible ways of European integration of the country;

inclusion of cross-border cooperation into the list of priorities listed in the Concept of National Regional Policy adopted in May 2001. This document states that one of the regional policy principles is "establishment of international cooperation in the field of regional policy, reshaping thenational legislation in this field to norms and standards of the European Union, and also development of cross-border cooperation as an effective tool to strengthen international relations and solve regional problems". The set of instruments for the impementation of national interests includes "promotion of development of cross-border and interregional economic links and integration, formation of respective commercial-financial groups, other forms of management";

formation of the new border between the European Union and Ukraine, i.e. adjusting the Western regions of Ukraine of the "external border"status, i.e. the status of the territories bordering upon the regions of Hungary, Slovakia, Romania and Poland which will receive 
considerable financial assistance from Structural Funds of the European Union, as their development level is lower than $75 \%$ of general European level.

opportunity to use cross-border cooperation experience gained by Western regions of Hungary and Poland which, during the 1990 s of the $20^{\text {th }}$ Century, functioned as "external regions" of the European Union and have access to the new forms of assistance from the EU.

Among the priorities and directions of the new EU policy, declared in Notification of European Commission to the European Council and European Parliament "Enlarged Europe - Neighbouring Countries. New structure of relations with our East and South neighbours" since 11 March 2003 it was emphasized that"part of the EU interest is cooperation as on bilateral, so on regional levels...", ambitious goal of which is "overcoming of core reasons of political instability, economic vulnerability, [...] poverty and social isolation". During 2004, the European Commission already presented small projects programmes Europe Aid (the former TACIS) in the field of border cooperation. The programme provides support forsmall projects aimed at cooperation between local and regional self-governments on Russian, Byelorussian, Ukrainian and Moldavian borders with the EU and countries-candidates for the accession to European Union. The priorities of the programme include administrative reforms, local economic development, social sector, problems in the field of environment and energy. The total indicative amount allocated for this programme makes 9.2 million Euros. There are two mechanisms in frames of the programme: the mechanism of small projects (grants up to 300 thousand Euros) and the mechanism of micro-projects (grants up to 50 thousand Euros).

In the message of European Commission "Preparing to introduction of new instrument for neighbourhood"5 since 1 July 2003 it was stated that the main aim of new cross-border cooperation should be adjusting thegoals to promote sustainable economic and social development of border regions in Europe, especially through involvement of "neighbour" border regions to European markets; joint solving of problems in the field of environment, health and crime; ensuring effectiveness and security on the borders, including fight against illegal migration; promotion of inter-personal contacts on border territories. It was planned to adjust these strategic goals in two stages: 2004-2006 - through coordination of priorities identifying and financial resources of traditional programmes such as TACIS, Phare, INTERREG (on the borders between the Central European countries and Ukraine, Moldova, Belarus and Russia). For the adjustment of the above mentioned, the "Programmes of good neighbourhood" were launched to involve the border regions. The project was to be prepared by the partners on both sides of the border and submitted to the European Commission. After 2006 - formation of separate and independent from the other programmes "instrument of good neighbourhood" which allows the partners to submit proposals to European Commission. The programme combines the elements of cross-border cooperation and regional development of border territories aiming at equalization of development levels of the regions separated by the borders.

Proposed new system of interrelation between Ukraine and European Union in the field of cross-border cooperation implementation is, in fact, a change of instruments (initiatives of

5 Прокладаючи шлях до нових інструментів розвитку сусідських відносин, http://www.kmv.gov.ua 
community INTERREG, Phare, TACIS) of financing - formation of an instrument based on coordination work held during the last years between INTERREG, Phare and TACIS programmes. Considering the role and essence of Neighbourhood programme provisions as not an axiom, let's emphasize, that in connection with Central European countries joining the EU, the Union of course involved neophytes to the INTERREG and other programmes, run by the EU member states. However, Ukraine was proposed a specific opportunity to form new instrument regulating the relations with neighbour countries, "based on positive experience in the field of cross-border cooperation in frames of Phare, "ACIS and INTERREG programmes". The European Commission identified three programmes and financial resources for the period of 2004-2006 for each of the programmes, involving Western border regions of Ukraine: Programme 1. Hungary-Slovakia-Ukraine $=4.0$ million Euros, Poland-Ukraine-Belarus $=8.0$ million Euros, Romania-Ukraine $=6.5$ million Euros .

At present, the European Commission strengthens cross-border cooperation through increasing activities on the external borders of the EU after the enlargement. This allows to intensify cooperation along all the EU borders, including those with Ukraine. In this regard, the proposals of the Commission provide opportunities for development on the external borders of the Union based on experience gained during implementation of European Community initiative INTERREG and also encourages further step towards coordination of our efforts in the border regions.

Let's emphasize that Ukraine was not proposed to participate in such a wide-scale and powerful financial programme as Phare (which approached Central European countries till May 2004) as the goal of that programme differed a lot from the goal of TACIS, that was implemented in Ukraine. And the goal always had and will have its strategic meaning such as preparing the Central European countries to access the European Union. The goal of the relations with Ukraine (based on this document) is to make a set of very careful steps with the country which, in fact, will defend new Eastern borders of the enlarged European Union.

From this point of view, the financially limited neighbourhood programmes (in accordance with the comparative European scale and available experience gained by Central European countries) again look rather miserable as for implementation of excessivelyambitious goals of the EU regarding "promotion of sustainable social-economic development of border regions and establishment of regional and cross-border cooperation". So what conclusion should Ukraine make out of this status quo? First and foremost, this is a task to use new available opportunities of cross-border cooperation with the EU as much effectively as possible, as it is already possible to cooperate with the "first-rate" neighbour countries of Ukraine in accordance with European standards and bigger financial capacities. Secondly, in this regard it is extremely important to follow European standards and form cross-border cooperation as an integral system with clearly defined priorities, forms and developed for joint implementation mutually beneficial specific cross-border programmes and projects on bi- and multi-lateral levels.

Spreading of the EU borders eastwards requires development of a strategy for using benefits of cross-border cooperation of Western regions of Ukraine with bordering territories of neighbour countries in new geopolitical situation. This would allow a neutralisation ofthe negative impact that will appear because of visa regime, introduction of new legislation 
regulating trade and migrationby neighbour countries. Cross-border cooperation is not effective in such a case when it is not followed by coordination of programmes. Thus, balanced development of border regions becomes possible only through development of joint programmes and formation of background for implementation of "mirror" projects. This stipulates for the need to develop joint strategic document in the nearest future, which would frame joint vision of cross-border cooperation development priorities in triune space Ukraine -Central Europe - European Union. The above listed geopolitical and other positive changes form, as for Ukraine, favourable conditions regarding the further improvement of cross-border cooperation with Western Central European neighbours and European Union in general for the sake of transition to the higher level of cooperation.

\section{Conlusion}

The end of $20^{\text {th }}$ - beginning of $21^{\text {st }}$ Centuries from the viewpoint of European choice of Ukraine, especially its search for general civilizational choice brought rather sad factors as lack of understanding the key role of euroregional cooperation, especially in the context of Ukraine's moving towards European integration. We mean, unfortunately, the absence of the system of cross-border/interregional cooperation in Ukraine. This is first. Secondly, in our opinion the reasons of such situation are "hidden" in wrong ideas of government representatives concerning inferiority of the regional and interregional cooperation within the general system of international relations (would like to emphasize - not inter-state relations). The regional factor, the more important it is within the international relations conducted by our country, is being considered as something, indifferent and unimportant. The principles of subsidiarity and decentralization, responsibility and capability of the regions of Ukraine did not gain suchinfluence demonstrated at least by our "first-rate" neighbours - Poland, Hungaryand Slovakia.

Hence, the similar attitude towards eurointegration of Ukrainian regions and cross-border cooperation in general (something like degrading, offensive, low-grade etc.) was observed within the international relations of Ukraine before, especially in case with Central European countries. The region of Central Europe was "forgotten" for Ukraine, and it remains the same today. Probably the only exclusion is active international cooperation between Ukraine and Poland. But again, along with loud declarations and statements about the necessity to gain experience, the attention is not paid at least to maximal use of extremely important and successful Polish experience in the field of building institutional structures and mechanisms of euroregional policy.

The analysis proves that after the EU enlargement in 2004 and access of the Central European countries to the EU, cross-border cooperation between Ukraine and Central-European countries (full member-states) entered the new stage of development. For sure, all the countries involved possession of political will and wish towards close cross-border interrelation and renewal of cooperation mechanisms. During the last years the legal base regulating international relations in the field of cross-border cooperation of Ukraine with Central European states - new EU members - has been enriched and considerably improved. International legislation and especially national system of regulation of cross-border relations were further developed. 
The geopolitical status of cross-border cooperation between Ukraine and Central European countries has been raised on the higher level. Ukraine has the capacity to solve problems of strengthening cross-border cooperation more effectively not only with each of Central European countries or their regional associations (Visegrad, Central European Initiative etc.) but directly with Brussels and Strasbourg - at the level of central European institutions. In its turn, Ukraine can agree and implement joint steps in frames of EU structures with each country - Western neighbour, for example, to receive financial support to implement joint cross-border projects.

Besides, during the last periodwe could observe an increase of practical interest of European institutions towards the development of cooperation with Ukraine especially on new Eastern borders of the EU. This is proved by the following:

Firstly, the management structures of the European Union declare and initiate strengthening and broadening of various forms of cooperation with Ukraine. On cross-border, interregional level, the relations Ukraine-EU, interrelations with the EU and EU member-states can become even more dynamic and effective than thoseon international level.

Secondly, the European structures encourage Central European countries located next to Ukraine to develop cross-border and interregional cooperation, in fact, entrusting Poland, Slovakia and Hungary to lead practical implementation of this direction as a part of the EU Eastern policy. The countries of Central Europe actively propose new plans and concepts of cross-border cooperation with Ukraine. Among those, it's worth to list joint Austrian-Hungarian and Niregyhaza initiatives since 2003, Concept for joint development of border regions of Ukraine and Hungary.

\section{Abstract}

The aim of this study was to analyze the transborder, interregional cooperation system in Central Europe in new geopolitical situation. Euroregional cooperation between neighbouring countries on both regional and local levels has become the most important element of European policy. Thus, the development of transborder cooperation between the bordering regions is a vital issue for the border territories of Ukraine and its first-rate neighbouring countries.

In the article the important component of the regional policy of the EU - the transborder cooperation is considered. The transformation of transborder cooperation of the EU and its components is analyzed, as well as the mechanisms and instruments of its implementationin the conditionsof the eurointegration process are defined.

\section{Keywords}

Central Europe, Ukraine, Integration, European Union, Enlargement, Transborder Cooperation, Geopolitical Situation 